Indonesian Journal of EFL and Linguistics

Vol. 3 No. 2, 2018

eISSN: 2503-4197, pISSN: 2527-5070

www. indonesian-efl-journal.org

\title{
The Use of Code Switching in General English Classes for Non-English Department Students in Indonesia
}

\author{
Thomas Wahyu Prabowo Mukti \\ Department of Language and Arts Education, Faculty of Teachers Training and \\ Education, Sanata Dharma University, Yogyakarta, Indonesia \\ e-mail: thomaswpm@gmail.com \\ Ouda Teda Ena \\ Department of Language and Arts Education, Faculty of Teachers Training and \\ Education, Sanata Dharma University, Yogyakarta, Indonesia \\ e-mail: ouda@usd.ac.id
}

\begin{abstract}
:
The issue of the use of code switching as instructional languages in the class has already become a worldwide concern. Some experts may say that it is beneficial while others believe that it is not since it may become the interference for the learning. Through this paper, the researchers want to investigate the use of code switching in General English Classes for non-English Department of Sanata Dharma University. Employing a quantitative approach, specifically observation method by recording the class activity, this study tries to find out the types and analyze code switching employed by lecturers in the classes. The data analyses revealed that tag switching, intra-sentential and inter-sentential code switching are employed by lecturers and the code switching itself functions as the topic switch, repetitive and affective function. The inter-sentential code switching was mostly used by the lecturer and it mostly served as a repetitive function to explain and show their affection to students Keywords: general English class for the non-English department, code switching, types of code switching, the function of code switching, instructional language.
\end{abstract}

Indonesian Journal of EFL and Linguistics, 3(2), 2018 


\section{INTRODUCTION}

The issues of the use of code switching as an instructional language in English as Foreign Language (EFL) classes may have been discussed for many years since code switching is a common thing used in multilingual Asian such as Indonesia (Liu, 2010; Mujiono, Poedjosoedarmo, Subroto, \& Wiratno, 2013). The consideration of using code switching as the strategy in the EFL classes is the claim that code switching can be helpful means for student's TL acquisition (Ahmad \& Jusoff, 2009a; Bista, 2009a; Jingxia, 2010; Makulloluwa, 2013; Modupeola, 2013a; N. Nguyen, Grainger, \& Carey, 2016; Nordin, Ali, Zubir, \& Sadjirin, 2013; Pollard, 2002b). In Indonesia, Sumarsih, Siregar, Bahri, and Sanjaya's (2014) study shows that code-switching is used for smoother communication in everyday life. Specifically, inter-sentential code switching was usually practiced intentionally to give students exposures while intrasentential code switching was found to be a habit of the English teacher as a bilingual (Fathimah, 2016a) and the code switching is able to assist teaching and learning activities in terms of Linguistic Semantics, and Pragmatics (Arung, 2015a; Mujiono et al., 2013). Further, a study done in Vietnam revealed that the idea of making full English classes in Non-English-speaking countries faces many challenges since classroom resources are inadequate, students' English competence, motivation, and autonomy are low, teachers' abilities are limited and teaching methods inappropriate (N. T. Nguyen, Grainger, \& Carey, 2016). Those are some teachers' considerations in employing code switching in EFL classes.

However, there are many teachers and/or researchers who oppose the use of code switching especially those who employ communicative techniques during classroom instruction (Sert, 2005a). In accordance to that fact, Fernandes (1997) as cited in (Pollard, 2002), believes that code switching is a linguistic deficit as the result of the speaker' lack of proficiency in both languages. It means code switching can be harmful to students since this situation makes student cannot communicate effectively in either language especially if the students do not master one of the languages employed. Further, repeated instruction in L1 after L2 may lead some undesired student behaviors and it may make students lose interest in listening to English instruction which means students' exposition to English is limited (Sert, 2005b). Although there are many contrast opinions related to the use of code switching as instructional language in the EFL classes, some studies proved that code switching is still beneficial for students and teachers both in terms of pedagogical and personal context (Arung, 2015b; Fathimah, 2016b; Maishara, Dieba, Ali, Intan, \& Syed, 2013; Makulloluwa, 2013; Modupeola, 2013b; Mujiono et al., 2013; N. T. Nguyen et al., 2016; Pollard, 2002c)

Specifically, the issue of the use of code switching in the EFL classes also occurs in Sanata Dharma University, which requires their students from all departments to be able to speak English for daily conversation. Based on the university policy, the ability to speak English becomes a requirement for students before they can graduate from university. All students from non-English Department of Sanata Dharma University are required to pass English Proficiency Test which is equivalent to the $\mathrm{C} 1$ level of CEFR (Language Institute, 2015; Siwi, 2015). The students are interviewed by the 
English department lecturers in face to face situation in which students are asked based on their way answering and responding the questions (Siwi, 2015). This strategy seems to have some deficiencies since it creates too much burden for students since most students had negative affective attitudes towards English Proficiency test.

Thus, in 2015, Sanata Dharma University proposed a general English subject as an obligatory subject to replace the English Proficiency test. In this class, students learn English guided by a lecturer and assistant lecturers in each class. The goal of general English class is to help students be able to communicate using basic English words which also cover reading, writing, listening and speaking skills. After finishing the subject, students are expected to be able to understand the main ideas of some passages in English, writing a short essay, understand the information from audio sources and express the idea (Language Institute, 2015). Further, if students can pass this class, they do not need to take the English Proficiency test.

However, most of the students' English proficiency and comprehension are not yet satisfactory like most Indonesians who learn English for the first time or not intensively (Arung, 2015b). It can be figured out from the writers' observation as an assistant lecturer for three periods. In the classes, lecturers try to give the students as much as English exposure they can give both by providing authentic materials and comprehensive tasks. However, it seems that students still do not really understand the explanation and instruction in the process, especially when lecturers uttered full English in the class. The students' low English proficiency and comprehension make the students' language acquisition also low. Further, based on the program evaluation, the materials on the students' handbook is also too hard for the students' level. It somehow adds another burden to students. Although lecturers provide some activities to help students, however, the activities were somehow ineffective since students did not really understand the lecturers' instructions uttered in English.

These phenomena created a gap between lecturers who ideally always speak in English and students whose English proficiency and comprehension are low. To overcome these gaps, the lecturers and the assistant lecturers employed the students L1, Indonesians, as the strategy. The L1 became the media for helping students. The lecturers shifted from English to students' L1, vice versa, in some occasion to explain some difficult words or concepts, giving instruction in English, asking students, introducing a new unit (Kasperczyk, 2005) and to check students' understanding. Further, the code switching helps teachers to construct knowledge across the curriculum for the students and at the same time build relationships with their students (Camillery, 1996). This phenomena even happens in the class of students with a higher level of English proficiency (Mukti \& Muljani, 2016). In this paper, the writers would like to find out the types of code switching based on Poplack (1980) and the functions of code switching based on Flyman-Mattsson \& Burenhult (1999) employed by lecturers in the General English classes and its implication. 


\section{LITERATURE REVIEW}

\subsection{Types of Code Switching}

Code switching is the phenomenon when the speaker(s) shift the languages used within the same speech for different purposes(Gumperz, 1982; Milroy, L., \& Muysken, 1995; Myers-Scotton, 2006; Poplack \& Sankoff, 1984). It means that code switching usually happens when speakers shift from one language to another whether it is only one word, utterance, and even one sentence but still in the same discourse. Thus, code switching is the shift of languages in the same speech or conversation whether it is only one word, utterance, and even one sentence.

The writers would like to employ Poplack's and Wardhaugh types of code switching. Poplack (1980) states that there are three types of code switching. They are tag switching, intra-sentential, and inter-sentential code switching. Here are the types of code switching.

\subsubsection{Tag Switching}

In tag switching, the code switching involves the insertion of a tag in one language in another language. Poplack (1980) considers that tag switching is less intimate. The tag-switching is often heavily loaded with ethnic content and would be placed low on a scale of translatability (p. 589). People use the tag in their utterances on many occasions. Poplack (1980) also considers that tag switching is the most frequently used switching because tags are freely moveable constituents which may be inserted almost anywhere in the sentence without fear of violating any grammatical rule (p. 589). In short, tag switching is a switch that happens when people insert a tag(s) from different languages in their speech and it happens most of the time because the tag does not violate the grammatical rule of the language.

\subsubsection{Intra-sentential Code Switching}

The intra-sentential code switching occurs within the clause or sentence boundary Poplack (1980). She referred this switch as a more complex or 'intimate' type, since a code-switched segment, and those around it must conform to the underlying syntactic rules of two languages which bridge constituents and link them together grammatically (p. 589). Using intra-sentential code switching, the speaker is trying to connect the switches with the utterance he is uttering and the switches occur within the boundary. Thus, intra-sentential code switching occurs within the sentence and the switch links the two languages.

\subsubsection{Inter-sentential Code Switching}

The inter-sentential code switching occurs at a clause or sentence boundary where each sentence is in one language and another (Poplack, 1980, p. 590). The code switching that mostly used by people who master the language to people who have low language mastery. It can be found when teachers teach their students. In summary, the inter-sentential code switching occurs in a different sentence but in the same speech. 


\subsection{The Functions of Code Switching}

Teachers' use of code switching is not always performed consciously; which means that the teacher is not always aware of the functions and outcomes of the code switching process (Jingxia, 2010; Modupeola, 2013b; Sert, 2005b). The use of code switching itself is reported as a restriction on the acquisition of English, however, some studies show that the use of code switching can actually aid the English teaching and learning (N. T. Nguyen et al., 2016). Thus, the writers would like to find out the functions of code switching in the EFL classes based on (Flyman-Mattsson \& Burenhult, 1999) findings by observing three classes of General English at Sanata Dharma University. Those functions are topic switch, affective functions, and repetitive functions. The sections below provide an overview of these functions.

\subsubsection{Topic Switch}

Teachers/lecturers may speak in students' L1 in the class. The lecturers/teachers exploit students' previous first language (L1) learning experience to increase the students understanding of the new language (Camillery, 1996; Clarke, 2008; Moore, $2002 \mathrm{~b}$ ). The topic switch can be seen in cases where the teacher alters his/her language according to the topic that is under discussion (Bensen \& Çavuşoğlu, 2013, p. 71). Bensen and Çavuşoğlu (2013) add that the code switching creates a link from known (native language) to unknown (new foreign language content) to transfer the clarity of new content and meaning (p. 71) or in the other words, a code-switch can be a bridge to fill the gap in the discourse in the class (Moore, 2002a; Sert, 2005b). Further, it can be used as a communicative resource in constructing knowledge across the curriculum (Camillery, 1996) which support group dynamics (N. T. Nguyen et al., 2016) help students to understand more the instructions, goals, and materials. For those reasons, code switching used by lecturers or teachers is expected to be a media for bridging the students' previous knowledge with new knowledge.

\subsubsection{Affective Functions}

Some lecturers/teachers may code switch to show their affection towards their students since code switching carries out affective functions (Bensen \& Çavuşoğlu, 2013 , p. 72). In this respect, code-switching is employed to build solidarity and good rapport with the students (Sert, 2005, p. 4). The switch contributes to the ability of the teachers to create a supportive language environment in language learning classrooms (Bensen \& Çavuşoğlu, 2013, p. 72) and it can help teachers build relationships with students (Camillery, 1996). Further, studies done in Vietnam and Malaysia show that the use of code switching can establish good rapport between teachers and students and create a friendly classroom atmosphere for students (Ahmad \& Jusoff, 2009; N. T. Nguyen et al., 2016). Thus, the code switching acts as the way the lecturers/teachers to express their emotion and to build solidarity to create a good atmosphere in the class.

\subsubsection{Repetitive Function}

In repetitive function, teachers use code-switching to transfer the necessary knowledge to the students in order to convey clarity (Sert, 2005b, p. 4) to avoid 
misunderstanding since the students might be unfamiliar with similar words in English (Bista, 2009). However, code switching can be a useful strategy in classroom interaction if the aim is to make meaning clear and to transfer the knowledge to students in an efficient way. In order to clarify the instructions, teachers/lecturers code-switch from a target language to a native language. Teachers may employ code switching in explaining new vocabularies and grammars, checking comprehension, and making a comparison between English and the students' first language $(\mathrm{N}$. T. Nguyen et al., 2016) in order to get a deeper understanding on what students are learning.

However, the tendency of repeating the instruction in the native language may lead to some undesired student behaviors (Sert, 2005, p. 4). In other words, when students get used to instructions being translated into their native language, they may lose interest in listening to the former instruction, which will have negative academic consequences as the students will have limited exposure to the foreign language discourse (Sert, 2005, p. 4).

\section{RESEARCH METHOD}

This research employed the quantitative method in order to collect and analyze the data (Ary, Jacobs, Sorensen, \& Razavieh, 2010). The writers gathered the data by doing observation six times on 30 September 2016, 3 October 2016, 7 October 2016 (two classes), 10 March 2017 and 25 March 2017. The researcher recorded the data on the use of code switching on Economic, Guidance and Counseling and Primary School Teacher Education Study Program of Sanata Dharma University. The recording data itself is around 900 minutes.

It has to be noted that not all classes have different characteristics based on the lecturers' style. Two lecturers (Ms. X and Mr. Z: late 20s) employed lots of code switching while one lecturer (Mr. Y: late 40s) preferred to use English most of the time. Moreover, in this data, the writers also had chances to record the assistants' lecture on a class. The assistants were around 20-22 when this study was done.

The recordings were later transcribed into the data of this study. The writers only transcribed the conversation and instruction that contain code switching. The data were classified into group A, B, C, D, E, and F respectively based on the date of the observation done. A and B are for Ms. X classes, $\mathrm{C}$ and D are for Mr. Y classes, E and $\mathrm{F}$ are for Mr. Z classes while the CA and DA are the representatives for the assistants in the Mr. Y class. Later on, the writers analyzed the data in order to reveal the types and functions of code switching employed by lecturers.

\section{THE FINDINGS AND DISCUSSION}

\subsection{FINDINGS}

Based on the findings, the writers analyzed the data into two big themes. They are types of code switching and the function of code switching. Here are the findings: 


\subsection{The Types of Code Switching}

There were three types of code switching employed by the lecturers, namely, tag switching, intra-sentential code switching, and inter-sentential code switching. Each will be described in the following parts.

Figure 1. The types of code switching employed by lecturers

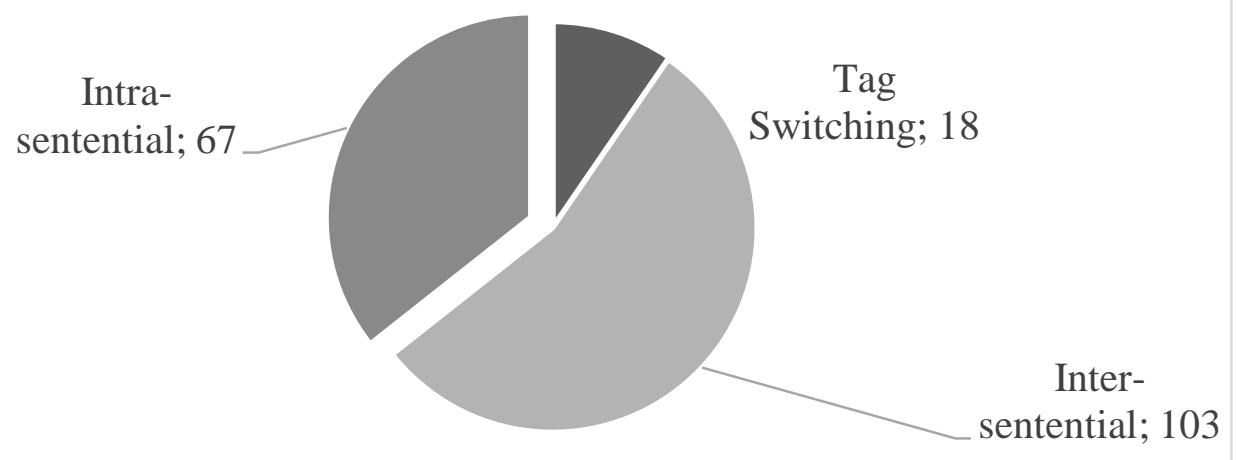

The data from figure 1 shows that inter-sentential code switching is the type of code switching which was mainly employed by the lecturers. Intra-sentential code switching was also employed by lecturers but not as much as the inter-sentential code switching while tag switching was rarely used by lecturers.

\subsubsection{Tag switching}

Tag-switching is a switch that happens when people insert a tag(s) from different languages in their speech and it happens most of the time because the tag does not violate the grammatical rule of the language (Poplack, 1980, p. 589). The writers discovered that the lecturer employed tag switching in their speech especially to quote or use the Indonesian or Javanese terms. The examples of the tag switching employed by the lecturer can be seen below.

[1] Di sini maknanya adalah verb, kata kerja to.. NO? (A14)

[2] Dalam grup kalian If I am not mistaken. Ya? (B12)

[3] Inspire, hah? Inspire? C4

In this study, the lecturer employed the tag switching for different reasons. In the first example, the lecturer used " $t$ " to confirm the students' answer. It happens also in example 2. The lecturer used " $y a$ " to confirm the agreement that they had made before. While on example 3, the lecturer used "hah", to show his disagreement on students answer.

Tag switching rarely happened in this study since Indonesians do not tend to use the tag in their speech. It is different from what Poplack (1980) states that tag switching is the switching that mostly happens in conversation. In this study, there were only 18 occurrences. It means that lecturers did not really employ this kind of code switching. It might because the environment did not support them to use the tag and there are limited tags in Indonesia. 


\subsubsection{Intra-sentential Code Switching}

The intra-sentential code switching occurs within the clause or sentence boundary (Poplack, 1980, p. 589) and it links two languages used by the speakers. The writers found that lecturers, especially Mr. Z, employed the intra-sentential code switching on their speech (67 times). Here are the examples of Intra-sentential code switching employed by the lecturer.

[4] Ada kata lain mungkin selain kata bodoh atau dungu for ignorant? Tidak mau tau iya, atau kata lainnya tidak peduli, ketidakpedulian (A11)

[5] So, again, whenever you are going to express, mengungkapkan, routine or habit please use simple present tense. (E13)

[6] Lha ini kurang apa? Spellingnya kurang apa? (F7)

The data above shows that the intra-sentential code switching is interconnected with the main sentence the speaker is uttering. The first example shows that the lecturer employed the intra-sentential code switching in the form of "for ignorant" and the switch is still interconnected with the main sentence. In addition, Mr. Z code-switched from English to Indonesia in example [5] while on example [6], he code-switched from Indonesia to English. In the example [5], he tried to explain the keyword in his instruction which is "express" by saying "mengungkapkan" which is more familiar to students. In the example [6], the switch was used to emphasize on the spelling mistake students made.

In short, the intra-sentential code switching employed by the lecturers is still connected with the sentence that the lecturer uttered. The switches employed do not stand alone. It most likely links the L1 and L2 of the speakers and it serves as a medium for explaining and emphasizing things or materials considered important by the lecturers.

\subsubsection{Inter-sentential Code Switching}

The inter-sentential code switching occurs at a clause or sentence boundary where each sentence is in one language and another (Poplack, 1980). In this study, the intersentential code switching is mostly used by the lecturers (103 times) which is in accordance with Jingxia's (2010) study in China. These are the examples:

[7] Have you read the text? Sudah dibaca textnya? (A2)

[8] Why this story is for children? Because when they hear a gingerbread jump from the oven, they will have no objection. Mereka tidak akan keberatan. (C5)

[9] To ask your friends about their habit or routine. You can use this question. Bisa menggunakan pertanyaan seperti ini. What do you do diikuti time? What do you do in the morning, what do you do in the evening, what do you do every Monday. (F37)

The inter-sentential code switching is the switch that mostly employed by the lecturers (103 times) in this research instead of the tag switching as mentioned by (Poplack, 1980). The first example shows that the lecturers employed the inter-sentential code 
switching in the form of repetition for the sentence she uttered before. It becomes the way the lecturer confirmed her question so students will truly understand it. The example [8] shows that the lecturer emphasized what he had said by repeating it in Indonesian. It happens also to example [9]. In the middle of his instruction, he repeated the instruction using Indonesia.

The data analysis shows that the inter-sentential code switching is the switch that mostly used by the lecturer in this research. From those data, it can be concluded that the inter-sentential code switching used by the lecturers was usually in the form of repetition. The lecturer used that form of switch mostly to confirm and make the instruction and explanation clearer.

\subsection{Function of Code Switching}

From the data finding analysis based on Flyman-Mattsson and Burenhult's (1999) study, the writers could conclude that the lecturer employed code switching for three reasons. They are as the topic switch, repetition, and affection. Here are the findings:

Figure 2. The functions of code switching employed by lecturers

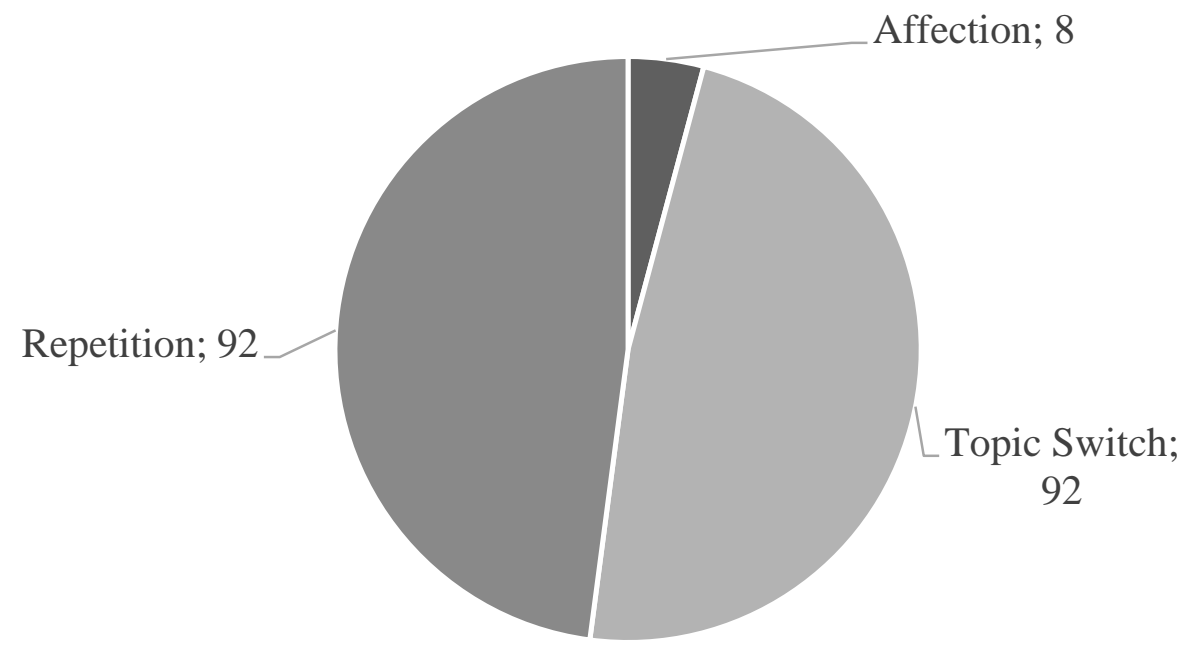

The findings above show that lecturers employed all functions of code switching in the classroom as proposed by Flyman-Mattsson and Burenhult (1999). Topic switch and repetition were the most functions employed by lecturers ( 92 times). On the other hand, it was rare for lecturers to employ code switching to show their affection to students.

\subsubsection{Topic Switch}

In this study, lecturers often employed code switching as the topic switch (92 times) especially to create a link from known (native language) to unknown (new foreign language content) in order to transfer the clarity of new content and meaning (Bensen \& Çavuşoğlu, 2013). However, in this study, lecturers used code switching to get the students' attention. These are the examples. 
[10] Bahwa yang diutamakan adalah hasil bukan the output of education without take* a look at the creativity of the students, or the discipline or the intelligence. (A32)

[11] Coba, you observe children when you do PKL or PPL. (C7)

[12] Simple present tense tidak ada yang namanya ing, ing, ing. Is it clear? (F41)

The findings above show that lecturers used code switching to actually clarify their instruction. In this case, it becomes the bridge for the students' L1 and L2. Example [10] shows that the lecturer used code switching to start talking about a topic by saying "bahwa yang diutamakan adalah hasil bukan ...." (the focus is on the result not...). She was trying to start a discussion related to the education concern.

Lecturers employed code switching as the way to get students' attention. It can be observed on example [11]. The lecturer said, "coba" (please try to) which became the indicator to help the student understand the topic that he was going to discuss which is the future subject that students will have: PPL and PKL (pre-service teaching). In this case, the lecturer was trying to build the students connection to it.

While on the example [12], the lecturer employed code switching to make students understand the concept of present tense by saying "Simple present tense tidak ada yang namanya ing, ing, ing". In this case, "tidak ada yang namanya" is the way the lecturer emphasized and clarify the concept of the present tense. The "-ing, -ing" is actually the way the lecturer said that in the present tense, there is no verb-ing or gerund.

In this study, code switching as the topic switch function acts as a good means to clarify lecturers' instructions and explanation and to even help lecturers to get students' attention.

\subsubsection{Affective}

In this research, the three lecturers and the assistant lecturers also employed code switching to show their affection to their students although it was not often (8 times). The code-switching in this study was employed to build solidarity and good rapport with the students (Ahmad \& Jusoff, 2009b; N. T. Nguyen et al., 2016; Sert, 2005). Here are the examples of the code switching employed by the lecturer that performs as the affective function.

[13] Ada yang bisa ditambahkan?Mungkin ada yang mau menyanggah? Tidak seperti itu Miss, tapi seperti ini. You are free to talk. (A35)

[14] I assume that you can find out how to find words by yourself. Saya mengansumsikan teman-teman bisa mengetahui caranya mengucapkan yang benar. Find out on the dictionary. (E10)

[15] Saya langsung cek di internet. Kalau ketahuan. I will give you zero because it is plagiarism. (F50) 
Example [13] shows that the lecturer was trying to encourage her students to express their ideas in English. Even, she used Indonesian sentences to show that it was okay to express their ideas. Thus, she added her encouragement by saying "You are free to talk". She was trying to create a supportive language environment in language learning classrooms (Ahmad \& Jusoff, 2009a; Bensen \& Çavuşoğlu, 2013; N. Nguyen et al., 2016).

Different ways of using code switching are shown by Mr. Z on example [14] and [15]. On the example [14], he used the phrase "teman-teman" to show his solidarity to his students. That phrase is considered as the way Indonesians saying that they are on the same level. Thus, Mr. Z in this situation showed that he was the students' friend in the context that he believed in his students had done what he expected. However, on the example [15], he showed his authority in the class by saying "Kalau ketahuan (If I know (that you copy it)). I will give you zero because it is plagiarism." He was not joking about it and he emphasized it by saying "kalau ketahuan" as the indicator of his seriousness.

Those three examples show that code switching could act as the way the lecturers express their emotion, build solidarity and even their authority. Although it was rarely employed, the findings of the use of code switching to show lecturers' affection toward their students could already show that all lecturers were trying to build good rapport and atmosphere for helping students learn more comfortably.

\subsubsection{Repetitive}

The data analyses of this study also revealed that the code switching employed by the lecturer can also serve as a repetitive function. This function was the most common type of function that the lecturers use (92 times). Here are the examples.

[16] Have you read the text? Sudah dibaca textnya? (A2)

[17] What is not afraid to be great? What is not afraid to be great? Yang gak takut menjadi besar itu apa? (C2)

[18] You can face your friend so they can see you! Kamu bisa menghadap ke teman-teman jadi teman-temanmu bisa melihatmu! (DA3)

[19] Questions of habit. Pertanyaan tentang kebiasaan atau rutin. (F36)

The data above show that the repetition may appear in the different context. It can be in the form of questions as shown on the example [16] and [17]. It can be also in the form of instruction like on the example [18]. However, mostly lecturers used it when they explain some things to students as on example [19]. The writers concluded that the lecturers tried to clarify their instruction, question, and explanation to students. This finding is in accordance with most studies which found out that code switching could be employed to clarify instructions and explanations (Jingxia, 2010) The use of code switching in the form of repetition can be understood since most of the students' English proficiency is not yet good. Sert (2005) mentions that teachers use code switching to transfer the necessary knowledge to the students in order to convey clarity and one the ways they chose is by code-switching. Similarly, Huerta-macías 
\& Quintero (2010) states that code switching can be mean to elaborate, emphasize, specify an addressee and to clarify for effective communication. In conclusion, the repetitive functions serve as means for lecturers to clarify their instructions and explanations.

\section{DISCUSSION}

This study finds that the use of code switching in the class of non-English department is different from the use of code switching in daily communication. It can be seen from the fact that tag-switching was not used a lot in this study which is different with Poplack's (1980) study which mentions that tag switching is the most-commonly-used code switching. It can be understood since the situation is more formal than in daily communication so that the language style used is also more formal since some tags are considered informal in Indonesia (i.e. " $y a$ ", " $t o ")$.

Furthermore, the code switching in this study was mostly used for explaining and emphasizing things or materials in the form of inter and intra-sentential codeswitching. It becomes the bridge for the L1 and L2 of the non-English department students as in Sert's (2005) study. Basically, the code-switching was used to link some information from the unknown language to known language. In addition, code switching was also used to clarify lecturers' instruction or explanation which is usually in the form of repetition or direct translation of sentences uttered previously.

This study also finds that code switching became the mean for shorting the gap between lecturers and students. The three lecturers were trying to be friendly with the students. It was seen through the use of "teman-teman" or "guys" to address the students as found in the affective function. Most lecturers were friendly and accommodative to their students. However, the use of that phrase is also affected by the lecturers' age. Ms. X, Mr. Z, and the assistants tend to address students with "guys" or "teman-teman" while Mr. Y tends to directly instruct or explain something without addressing who was the audience.

Lastly, lecturers in this study used code switching consciously. The phenomenon of repetition in the form of inter-sentential code switching employed by lecturers shows that lecturers did aware of students' condition and they might consider that it is necessary to repeat their instruction using Indonesians. Further, it means that the materials for this class should not be too hard since students' vocabularies are very limited so lecturers consider that they have to explain directly by code-switching. These findings mean that the organizer needs to reconsider again the students' English level and they might revise and produce easier materials for students which less burdening.

\section{CONCLUSION}

In conclusion, the code switching employed in the General English classes is inevitable. It is in accordance with the fact that the students were lack of English proficiency and comprehension so that lecturers consciously used code switching for helping their students understand materials and instruction better. There were three types of code switching employed by the lecturer in this research, namely tag 
switching, intra-sentential and inter-sentential code switching. Unlike Poplack's (1980) study, this study shows that inter-sentential code switching was the most used code switching. In addition, the code switching employed in this research also had three functions, namely topic switch, repetitive and affective function. The code switching mostly served as a repetitive function which is in accordance with the finding that inter-sentential code switching was mostly employed by lecturers to repeat their instruction or explanation. In summary, code switching employed by lecturers in General English class was needed to clarify lecturers' explanations and instruction to help students acquire TL, therefore, it is not true that code switching mostly hinder students' learning.

\section{Acknowledgments}

The authors would like to acknowledge all lecturers of General English classes of Sanata Dharma University, Yogyakarta, Indonesia who have become the participants, especially for their support and contribution to this project.

\section{Disclosure statement}

No potential conflict of interest was reported by the authors.

\section{REFERENCES}

Ahmad, B. H., \& Jusoff, K. (2009). Teachers' code-switching in classroom instructions for low English proficient learners. English Language Teaching, 2(2), 49.

Arung, F. (2015). The Role and the Use of Indonesian Language in the Teaching and Learning English as a Foreign Language. Advances in Language and Literary Studies, 6(5), 242-249.Ary, D., Jacobs, L.C., Sorensen, C., \& Razavieh, A. (2010). An introduction to research in education. Belmont: Wadsworth.

Bensen, H., \& Çavuşoğlu, Ç. (2013). Reasons for the teachers' uses of codeswitching in adult EFL classrooms. Hasan Ali Yücel Eğitim Fakültesi Dergisi, 10(2), 69-82.

Bista, K. (2010). Factors of Code Switching among Bilingual English Students in the University Classroom: A Survey. Online Submission, 9(29), 1-19. Retrieved from http://eric.ed.gov/?q=code+switching++english\&id=ED525827 on 27 July 2017.

Camilleri, A. (1996). Language values and identities: Code switching in secondary classrooms in Malta. Linguistics and education, 8(1), 85-103.

Cole, S. (1998). The use of L1 in communicative English classrooms. Language Teacher-KYOTO-JALT, 22, 11-14.

Creswell, J. (2009). Research design: Qualitative, quantitative and mixed methods approaches. Los Angeles: SAGE Publications Inc.

Fathimah, D. N. (2016). Why is There Code Switching in EFL Classroom?: a Case Study in a Vocational School in Cimahi West-java. Jurnal Pendidikan Bahasa dan Sastra, 16(1), 70-77. 
Fernandez, R. M. (1990). Actitudes hacia los cambios de ctfdigos en Nuevo M6xico: Reacciones de un sujeto a ejemplos de su habla. Spanish in the United States: Sociolinguistic Issues, 49. Georgetown University Press. Washington D.C., in Pollard (2002).

Flyman-Mattsson, A., \& Burenhult-Mattsson, N. (1999). Code-switching in second language teaching of French. Working papers, 47, 59-72.

Gumperz, J. J. (1982). Discourse strategies (Vol. 1). Cambridge: Cambridge University Press.

Holmes, J. (1992). An introduction to sociolinguistics. London: Longman.

Huerta-Macias, A., \& Quintero, E. (1992). Code switching, bilingual and biliteracy: Case study. Duluth: University of Minnesota.

Jingxia, L. (2010). Teachers' code-switching to the L1 in EFL classroom. The Open Applied Linguistics Journal, 3(10), 10-23.

Kasperczyk, L. (2005). Implementing code-switching in the classroom. (Unpublished undergraduate thesis). New York: Daemen College, Amherst.

Language Institute. (2015). Panduan mata kuliah bahasa Inggris. Yogyakarta: Universitas Sanata Dharma.

Nordin, N. M., Ali, F. D. R., Zubir, S. I. S. S., \& Sadjirin, R. (2013). ESL Learners Reactions Towards Code Switching in Classroom Settings. Procedia-Social and Behavioral Sciences, 90, 478-487.

Makulloluwa, E. (2013). Code switching by teachers in the second language, 6(3), 581-598.

Milroy, L., \& Muysken, P. (Eds.). (1995). One speaker, two languages: Crossdisciplinary perspectives on code-switching. Cambridge University Press.

Modupeola, O. (2013). Code- Switching as a teaching strategy: Implication for English Language teaching and learning in a multilingual society. IOSR Journal Of Humanities And Social Science, 14(3), 92-94.

Moore, D. (2002). Code-switching and learning in the classroom. International journal of bilingual education and bilingualism, 5(5), 279-293.

Mujiono, Poedjosoedarmo, S., Subroto, E., \& Wiratno, T. (2013). Code switching in English as foreign language instruction practiced by the English lecturers at universities. International Journal of Linguistics, 5(2), 46.

Mukti, T. W. P., \& Muljani, R. (2016). Code switching in the instructions of English language education study program lecturers. Language and Language Teaching (LLT), 19(1), 46-60.

Myers-Scotton, C. (2006). How codeswitching as an available option empowers bilinguals. Contributions to the Sociology of Language, 92, 73.

Nguyen, N. T., Grainger, P., \& Carey, M. (2016). Code-switching in English language education: Voices from Vietnam. Theory and Practice in Language Studies, 6(7), 1333.

Pollard, S. (2002). The benefit of code switching within a bilingual education program. Honors Projects, 1-17.

Poplack, S. (1980). Sometimes I'll start a sentence in Spanish y termino en Espanol: toward a typology of code-switching1. Linguistics, 18(7-8), 581618. 
Poplack, S., \& Sankoff, D. (1984). Borrowing: The synchrony of integration. Linguistics, 22(1), 99-136.

Sert, O. (2005). The functions of code-switching in ELT classrooms. Online Submission, 11(8).

Siwi, A. P. T. (2015). Students' attitudes towards spoken English competence test (TKBI) at university level. (Unpublished master thesis). Sanata Dharma University, Yogyakarta, Indonesia.

Wardaugh, R. (2006). An introduction to sociolinguistics. West Sussex: Wiley Blackwell. 